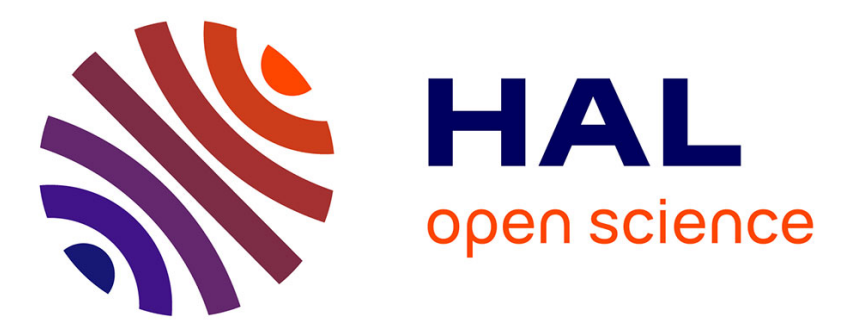

\title{
In vitro effect of vaginal lactobacilli on the growth and adhesion abilities of uropathogenic Escherichia coli
}

María Cecilia Leccese Terraf, María Silvina Juarez Tomás, Lucie Rault, Yves Le Loir, Sergine Even, María Elena Fátima Nader-Macías

\section{- To cite this version:}

María Cecilia Leccese Terraf, María Silvina Juarez Tomás, Lucie Rault, Yves Le Loir, Sergine Even, et al.. In vitro effect of vaginal lactobacilli on the growth and adhesion abilities of uropathogenic Escherichia coli. Archives of Microbiology, 2017, 199 (5), pp.767-774. 10.1007/s00203-016-1336-z . hal-01593193

\section{HAL Id: hal-01593193 \\ https://hal.science/hal-01593193}

Submitted on 25 Sep 2017

HAL is a multi-disciplinary open access archive for the deposit and dissemination of scientific research documents, whether they are published or not. The documents may come from teaching and research institutions in France or abroad, or from public or private research centers.
L'archive ouverte pluridisciplinaire $\mathbf{H A L}$, est destinée au dépôt et à la diffusion de documents scientifiques de niveau recherche, publiés ou non, émanant des établissements d'enseignement et de recherche français ou étrangers, des laboratoires publics ou privés. 


\title{
In vitro effect of vaginal lactobacilli on the growth and adhesion abilities of uropathogenic Escherichia coli
}

\author{
María Cecilia Leccese Terraf ${ }^{1} \cdot$ María Silvina Juarez Tomás ${ }^{1} \cdot$ Lucie Rault $^{2}$ • \\ Yves Le Loir ${ }^{2}$ Sergine Even² ${ }^{2}$ María Elena Fátima Nader-Macías ${ }^{1}$
}

Received: 15 November 2016 / Revised: 3 December 2016 / Accepted: 28 December 2016 / Published online: 9 March 2017

(C) Springer-Verlag Berlin Heidelberg 2017

\begin{abstract}
Escherichia coli is one of the main causes of uncomplicated urinary tract infections and responsible of vaginal infections. Lactobacilli can inhibit this pathogen by the production of antimicrobial substances as organic acids, hydrogen peroxide and/or bacteriocins. The aim of this work was to study the effects of beneficial vaginal lactobacilli on E. coli through in vitro experiments. The inhibitory activity of three vaginal Lactobacillus strains against $E$. coli was assessed using the agar plate diffusion. Moreover, the effect of Lactobacillus reuteri CRL (Centro de Referencia para Lactobacilos Culture Collection) 1324 on the adhesion and internalization capabilities of E. coli was studied on HeLa cells. Two Lactobacillus strains inhibited the growth of the pathogens by production of organic acids. L. reuteri CRL 1324 reduced the adhesion and internalization of $E$. coli 275 into HeLa cells. The results obtained suggest that L. reuteri CRL 1324 can be considered as a probiotic candidate for further in vivo studies for the prevention or treatment of urinary tract infections caused by E. coli.
\end{abstract}

Keywords Lactobacillus $\cdot$ Escherichia coli $\cdot$ Organic acids $\cdot$ Adhesion $\cdot$ Internalization

Communicated by Erko Stackebrandt.

María Elena Fátima Nader-Macías

fnader@cerela.org.ar

1 Centro de Referencia para Lactobacilos (CERELA)CONICET, Chacabuco 145, 4000 Tucumán, Argentina

2 INRA, UMR 1253 STLO, Agrocampus Ouest, Rennes Cedex, France

\section{Introduction}

Urinary tract infections (UTI) are one of the most common infectious diseases worldwide and represent a very high economic cost to the public health system (Pitout and Laupland 2008). Escherichia coli is one of the most frequently isolated pathogen in nosocomial and community-acquired bacterial infections, including urinary tract, intestinal and systemic infections in humans (Pitout 2013), while uropathogenic Escherichia coli (UPEC) is the main cause of uncomplicated urinary tract infections. UPEC presents different virulence factors including adhesion determinants, motility, acquisition of metals, production of toxins and immune evasion (Mobley et al. 2009; Nielubowicz and Mobley 2010; Ejrnaes et al. 2011). Furthermore, some UPEC strains are able to generate intracellular bacterial communities and quiescent intracellular stores (Mysorekar and Hultgren 2006; Anderson et al. 2010). On the other hand, E. coli is associated with vaginal infection, such as vaginitis (Razzak et al. 2011).

The standard therapies for UTI include different antibiotics, which can alter the autochthonous microbiota and generate resistant strains (Beerepoot et al. 2012). Thus, alternative strategies for their treatment are urgently required because of the high level of resistance of microorganisms to conventional antimicrobials (Geerlings et al. 2014). In women with recurrent UTI, which often show persistent vaginal colonization with $E$. coli (Johnson and Russo 2005), the absence of Lactobacillus strains producing hydrogen peroxide appears to be determinant in the pathogenesis of recurrent UTI, facilitating the colonization with E. coli (Gupta et al. 1998; Atassi and Servin 2010).

The normal vaginal microbiome is dominated by lactobacilli (Human Microbiome Project Consortium 2012; Witkin 2015). The use of probiotic products containing vaginal 
lactobacilli has been proposed as an alternative treatment against infections by E. coli (Stapleton et al. 2011). Probiotics are defined as "live microorganisms which, when administered in adequate amounts, exert a beneficial physiological effect in the host health" (FAO/WHO 2001; Hill et al. 2014). Stapleton et al. (2011) reported the association of a reduction in recurrent urinary tract infection by the use of Lactin-V (Lactobacillus crispatus intravaginal suppository probiotic) after the standard treatment for cystitis.

Probiotics can exert beneficial effects by different mechanisms, such as production of antimicrobial substances (organic acids, hydrogen peroxide and bacteriocins) (Nader-Macías et al. 2008; Martín and Suárez 2010; Mirmonsef et al. 2012; Stoyancheva et al. 2014) and biosurfactants (Gudiña et al. 2010), modulation of immune system (Oelschlaeger 2010; Joo et al. 2011; De Gregorio et al. 2016) and biofilm formation (Martín et al. 2008; Leccese Terraf et al. 2012). Colonization capability, including adhesion to epithelial cells or mucosal surfaces that contribute to the beneficial effect through the time, is also one of the mechanisms suggested for probiotics (Nader-Macías et al. 2008; Bouchard et al. 2015). The aims of this work were: to evaluate the susceptibility of $E$. coli to antagonistic substances produced by lactobacilli, to determine the Lactobacillus reuteri CRL 1324 ability of adhesion to and internalization into human cervical HeLa cells, and to assess the $L$. reuteri CRL 1324 capability to counteract UPEC adhesion to and internalization into human cervical HeLa cells.

\section{Materials and methods}

\section{Bacterial strains and culture conditions}

Three vaginal Lactobacillus strains and two E. coli strains were used (Table 1). The three Lactobacillus strains were previously selected for their in vitro beneficial characteristics, such as production of hydrogen peroxide, inhibition of urogenital pathogens, auto-aggregation, adhesion to mucin and ability to form biofilm in culture media without Tween
80 (Juárez Tomás et al. 2005; Juárez Tomás et al. 2011; Leccese Terraf et al. 2012; Leccese Terraf et al. 2014). Lactobacilli were stored in yeast extract milk at $-20^{\circ} \mathrm{C}$ and sub-cultured twice in De Man-Rogosa-Sharpe (MRS) broth (De Man et al. 1960), for $12 \mathrm{~h}$ at $37^{\circ} \mathrm{C}$, under static conditions. A third sub-culture was performed in MRS and MRS without Tween 80 (MRS-T) and incubated for $12 \mathrm{~h}$ at $37^{\circ} \mathrm{C}$ (Leccese Terraf et al. 2012). MRS-T was used because this medium favored biofilm formation and allowed the growth of most of the Lactobacillus strains evaluated (Leccese Terraf et al. 2012).

Escherichia coli strains were isolated from human urine samples in Tucumán, Argentina, and identified by standard phenotypic techniques (Table 1). These microorganisms were stored at $-20^{\circ} \mathrm{C}$ in BHI (Brain Heart Infusion, composition in g/l: 200 infusion brain, 250 heart infusion, 10 peptone, $5 \mathrm{NaCl}, 2$ glucose and $2.50 \mathrm{Na}_{2} \mathrm{HPO}_{4}$ ) added with $20 \%$ glycerol. Before the experiments, each $E$. coli strain was sub-cultured in BHI broth for $12 \mathrm{~h}$ at $37^{\circ} \mathrm{C}$, under aerobic conditions without agitation. A second sub-culture was performed in BHI or LAPTg broth (Raibaud et al. 1973) prior to use.

\section{Susceptibility of $E$. coli to antagonistic substances produced by vaginal lactobacilli}

The antagonistic effect of the culture supernatants of vaginal lactobacilli on uropathogenic E.coli was determined by the diffusion technique on agar plate (Juárez Tomás et al. 2011). Lactobacillus supernatants (from the third sub-culture), obtained by centrifugation $(6000 \times g, 10 \mathrm{~min})$ were divided into three fractions. One fraction was assayed without treatment (crude supernatant), the second was neutralized with $\mathrm{NaOH}(2 \mathrm{~mol} / \mathrm{l})$, and the third one was neutralized and treated with catalase $(1000 \mathrm{U} / \mathrm{ml})$. Crude and treated supernatants $(25 \mu \mathrm{l})$ were seeded in agar plate holes ( $4 \mathrm{~mm}$ ) containing the different $E$. coli strains at three concentrations (Table 2). Each one of the E. coli strains was plated in BHI-1\% agar and LAPTg-1\% agar.

Table 1 Lactobacillus and E. coli strains used in this work

\begin{tabular}{ll}
\hline Lactobacillus strains & Source of strains \\
\hline $\begin{array}{ll}\text { Lactobacillus reuteri CRL } 1324 \\
\text { Lactobacillus rhamnosus CRL } 1332\end{array}$ & Isolated from human vagina (Ocaña et al. 1999a, b) \\
Lactobacillus gasseri CRL 1263 & \\
\hline Escherichia coli strains & Source of strains \\
\hline Escherichia coli 275 & Isolated from a patient with cystitis \\
Escherichia coli 36 & Isolated from a patient with pyelonephritis
\end{tabular}

$C R L$ from the Centro de Referencia para Lactobacilos Culture Collection 
Table 2 Growth inhibition of E. coli strains by vaginal lactobacilli with beneficial properties

\begin{tabular}{|c|c|c|c|c|c|c|c|c|}
\hline \multicolumn{3}{|c|}{ Culture media for lactobacillia } & \multicolumn{6}{|c|}{ Vaginal Lactobacillus strains } \\
\hline & & & \multicolumn{2}{|c|}{ L. reuteri CRL 1324} & \multicolumn{2}{|c|}{ L. rhamnosus CRL 1332} & \multicolumn{2}{|c|}{ L. gasseri CRL 1263} \\
\hline & & & MRS & MRS-T & MRS & MRS-T & MRS & MRS-T \\
\hline & & $\mathrm{pH}^{\mathrm{b}}$ & 4.27 & 4.58 & 4.08 & 5.08 & 4.68 & 5.42 \\
\hline E. coli strains & Culture media ${ }^{c}$ & Inoculum & \multicolumn{6}{|c|}{ Inhibitory halos in $\mathrm{mm}^{\mathrm{d}}$} \\
\hline \multirow[t]{6}{*}{36} & LAPTg & $3.21 \times 10^{8}$ & 7.5 & 8 & 8 & 0 & 0 & 0 \\
\hline & LAPTg & $3.21 \times 10^{7}$ & 6.5 & 6.5 & 8 & 0 & 0 & 0 \\
\hline & LAPTg & $1.61 \times 10^{7}$ & 8 & 6.5 & 8 & 0 & 0 & 0 \\
\hline & BHI & $3.21 \times 10^{8}$ & 5 & 0 & 6.5 & 0 & 0 & 0 \\
\hline & BHI & $3.21 \times 10^{7}$ & 5 & 5 & 5.5 & 0 & 0 & 0 \\
\hline & $\mathrm{BHI}$ & $1.61 \times 10^{7}$ & 0 & 5 & 5 & 0 & 0 & 0 \\
\hline \multirow[t]{6}{*}{275} & LAPTg & $3.10 \times 10^{7}$ & 5.5 & 5.5 & 6.5 & 0 & 0 & 0 \\
\hline & LAPTg & $3.10 \times 10^{6}$ & 7 & 7 & 10 & 0 & 0 & 0 \\
\hline & LAPTg & $1.55 \times 10^{6}$ & 10 & 8 & 9.5 & 0 & 0 & 0 \\
\hline & BHI & $3.10 \times 10^{7}$ & 4 & 3 & 4 & 0 & 0 & 0 \\
\hline & BHI & $3.10 \times 10^{6}$ & 5 & 3 & 6 & 0 & 0 & 0 \\
\hline & BHI & $1.55 \times 10^{6}$ & 5 & 4 & 6 & 0 & 0 & 0 \\
\hline
\end{tabular}

${ }^{\mathrm{a}}$ Culture media used for the growth of vaginal lactobacilli: MRS and MRS without Tween 80 (MRS-T)

${ }^{\mathrm{b}}$ Final $\mathrm{pH}$ of Lactobacillus cultures after $12 \mathrm{~h}$ incubation in MRS broth and MRS-T, at $37^{\circ} \mathrm{C}$.

${ }^{\mathrm{c}}$ Culture media used for the growth of E. coli strains: LAPTg and BHI broths

${ }^{\mathrm{d}}$ Halos of inhibition (in $\mathrm{mm}$ ) in agar plates produced by untreated supernatants of vaginal lactobacilli. Each value represents the average value of repetitions performed on different days

The plates were incubated for $5 \mathrm{~h}$ at room temperature and then for $24 \mathrm{~h}$ at $37^{\circ} \mathrm{C}$. The inhibition halos of the pathogen growth originated by the Lactobacillus supernatants were determined as millimeters.

\section{HeLa cells assay}

\section{Bacterial culture conditions}

L. reuteri CRL 1324 was used to assess the in vitro inhibitory capability against E. coli 275 infection in eukaryotic HeLa cells. Bacteria from the third sub-culture in MRS were washed once with phosphate-buffered saline (PBS) and resuspended at different concentrations in Dulbecco's modified Eagle's medium (DMEM; pH 7.4; D. Dutscher, Brumath, France). Bacterial numbers were estimated by a VWR V-1200 spectrophotometer at $650 \mathrm{~nm}$ (VWR, France) and by the viable cell numbers using a micro method previously described (Baron et al. 2006). The E. coli 275 population (in $\mathrm{CFU} / \mathrm{ml}$ ) was determined on MacConkey agar plates after $24 \mathrm{~h}$ of incubation at $37^{\circ} \mathrm{C}$. The L. reuteri CRL 1324 viable cells number was counted on MRS agar plates (pH 5.4) incubated for $48 \mathrm{~h}$ at $37^{\circ} \mathrm{C}$.

\section{HeLa cells and culture conditions}

HeLa cells were cultured in T75 cell culture flasks using DMEM medium containing 10\% heat-inactivated fetal calf serum (FCS). Cells were incubated at $37{ }^{\circ} \mathrm{C}$ in a humidified incubator with $5 \% \mathrm{CO}_{2}$. The HeLa cells were cultured to obtain a confluent monolayer, treated with $0.05 \%$ trypsin (Gibco-BRL, Grand Island, NY) and resuspended in fresh medium at a concentration of $2 \times 10^{5}$ cells $/ \mathrm{ml}$. Cells were counted in a Malassez chamber. For adhesion and internalization assays, cells were then seeded in 12 -well plates $\left(2 \times 10^{5}\right.$ cells/well) and incubated overnight at $37^{\circ} \mathrm{C}$ in $5 \%$ $\mathrm{CO}_{2}$ to obtain a confluent monolayer.

\section{Adhesion assays}

The adhesion assays were adapted from Almeida et al. (1996) and Bouchard et al. (2013), and modified as follows. Confluent monolayers of HeLa cells $\left(2.5 \times 10^{5}\right.$ cells/well $)$ were washed four times with PBS and incubated at $37^{\circ} \mathrm{C}$ in $5 \% \mathrm{CO}_{2}$ with $1 \mathrm{ml}$ of $E$. coli 275 suspension in DMEM at $2.5 \times 10^{7} \mathrm{CFU} / \mathrm{ml}$ to achieve a 100:1 multiplicity of infection (MOI; ratio of E. coli cells to HeLa cells). Adhesion assays with $L$. reuteri CRL 1324 were performed by adding $1 \mathrm{ml}$ of $L$. reuteri at $1.0 \times 10^{8} \mathrm{CFU} / \mathrm{ml}$ or $5.0 \times 10^{8} \mathrm{CFU} / \mathrm{ml}$ 
to achieve a 400:1 or 2000:1 ratio of interaction (ROI; ratio of $L$. reuteri cells organisms to HeLa cells). Adhesion of $E$. coli and $L$. reuteri was quantified at $1 \mathrm{~h}$ post-infection.

For the inhibition of adhesion assays, HeLa cells were incubated with $L$. reuteri CRL 1324 at a ROI of $400: 1$ or 2000:1 and E. coli 275 (MOI 100:1) for $1 \mathrm{~h}$ at $37^{\circ} \mathrm{C}$ with $5 \% \mathrm{CO}_{2}$. After the incubation steps, HeLa monolayers were washed four times with PBS and treated with $0.05 \%$ trypsin for $10 \mathrm{~min}$ at $37^{\circ} \mathrm{C}$. HeLa cells were centrifuged for $5 \mathrm{~min}$ at $800 \times g$ and lysed using $100 \mu \mathrm{l}$ of $0.01 \%$ Triton in sterile water. The population of bacteria adhered $(\mathrm{CFU} / \mathrm{ml})$ was determined using the micromethod as described before.

The adhesion assay of $E$. coli was used as a reference. Adhesion rates were defined as the adhered $E$. coli population in the presence of $L$. reuteri referred to the adhered $E$. coli population in the experimental procedure.

\section{Internalization assays}

Internalization assays were adapted from Almeida et al. (1996) and Bouchard et al. (2013) and modified as follows. Confluent monolayers of HeLa cells $\left(2.5 \times 10^{5}\right.$ cells/well $)$ were washed twice with PBS and incubated in $5 \% \mathrm{CO}_{2}$ at $37^{\circ} \mathrm{C}$ with $1 \mathrm{ml}$ of E. coli 275 and/or L. reuteri CRL 1324 suspension in DMEM, at a MOI of 100:1 for E. coli and a ROI of 400:1 or 2000:1 for L. reuteri CRL 1324. E. coli 275 and L. reuteri CRL 1324 internalization was quantified $2 \mathrm{~h}$ post-infection. For the inhibition of internalization assays, L. reuteri CRL 1324 and E. coli were simultaneously added to HeLa cells for $2 \mathrm{~h}$.

E. coli and $L$. reuteri CRL 1324 internalization was quantified at $2 \mathrm{~h}$ post-infection following an additional $2 \mathrm{~h}$ incubation step with DMEM supplemented with gentamicin $(100 \mu \mathrm{g} / \mathrm{ml})$. This step produced the killing of extracellular bacteria and allowed only the quantification of the internalized bacterial population. Subsequently, HeLa monolayers were washed four times with PBS, treated with trypsin, centrifuged for $5 \mathrm{~min}$ at $800 \times \mathrm{g}$, and lysed in $0.01 \%$ Triton. E. coli and L. reuteri populations were determined as described above.

The internalization assay of $E$. coli was used as a reference. Internalization rates were then defined as the internalized $E$. coli population in the presence of $L$. reuteri CRL 1324 referred to the internalized E. coli population in the experimental protocol.

\section{Statistical analysis}

Each experiment was done in triplicate (biological repeats). Statistical analysis was performed using $\mathrm{R}$ software ( $\mathrm{R}$ development Core Team 2013). The differences in adhesion and internalization capacities of $E$. coli in the presence of $L$. reuteri were assessed using one-way analysis of variance, considering as statistically significant a $p$ value lower than 0.05 .

\section{Results and discussion}

\section{Susceptibility of $E$. coli to antagonistic substances by lactobacilli}

The crude supernatants from $L$. reuteri CRL 1324 and $L$. rhamnosus CRL 1332 cultures inhibited the growth of UPEC strains, as shown in Table 2. L. reuteri CRL 1324 supernatants produced higher zones of inhibition when the pathogen was grown in LAPTg (halo size $=5.5-10 \mathrm{~mm}$ ) instead of BHI (halo size $=0-5 \mathrm{~mm}$ ). In general, the inhibition produced by $L$. reuteri CRL 1324 on the pathogens grown in LAPTg was higher when the inoculum of the pathogen in agar plates was lower. Similar inhibition patterns were obtained when $L$. reuteri CRL 1324 was grown in MRS and MRS-T. The L. rhamnosus CRL 1332 supernatants from MRS inhibited E. coli growth and the inhibition was higher when the pathogen was cultured in LAPTg. In the present work, the neutralized and catalase-treated supernatants did not show the inhibition of the pathogen, indicating that the inhibitory effect is by the production of organic acids (data not shown). L. gasseri CRL 1263 did not inhibit any of the two E. coli strains assayed.

The results reported in this work are in partial agreement with those published by several authors reporting that the inhibition of UPEC by lactic acid bacteria (LAB) isolated from human vagina is related to lactic acid production. However, production of hydrogen peroxide by these LAB strains was frequently published. Cadieux et al. (2009) have evidenced that the culture supernatants of L. rhamnosus GR-1 and L. reuteri RC-14 (isolated from human vagina and distal urethra and vagina, respectively) inhibited the growth of UPEC C1212 by lactic acid and hydrogen peroxide production. Also the expression of type 1 fimbriae and P (adhesion factors) was affected. Atassi and Servin (2010) showed that $L$. gasseri KS120, isolated from human vagina, produced lactic acid and hydrogen peroxide, acting cooperatively to inhibit enteric (Salmonella enterica serotype Typhimurium SL1344), vaginal (Gardnerella vaginalis DSM 4944) and urinary tract pathogens (E. coli CFT073). The potential inhibition of pathogens by LAB isolated from the urogenital tract has sometimes been associated to bacteriocin production. For example, Razzaket al. (2011) have published that four isolates of lactobacilli (from vaginal swabs) showed potent bacteriocin activity against $E$. coli and Staphylococcus aureus indicator isolates, while previous results have shown the inhibitory effect of salivaricin CRL 13218 (Ocaña et al. 1999a, b; Vera Pingitore et al. 2012) on pathogens. 
In healthy human vagina, a low $\mathrm{pH}$ limits the growth of different urogenital pathogens. E. coli colonization is not frequently isolated at low $\mathrm{pH}$, but the risk of infections increases when vaginal $\mathrm{pH}$ is close to neutrality (Falagas et al. 2006). O'Hanlon et al. (2013) suggested that when lactobacilli dominate the vaginal microbiota, women have more lactic acid mediating the protection against pathogens.

\section{Adhesion and internalization of $L$. reuteri CRL 1324}

Lactobacillus reuteri CRL 1324 was the strain that evidenced the highest E. coli inhibition. Therefore, this Lactobacillus strain was selected to assay its adhesion and internalization abilities into HeLa cells. L. reuteri (a heterofermentative bacterium) is considered as one of the Lactobacillus species autochthonous to humans and animals hosts (Hou et al. 2015).

The results demonstrated that the adhesion abilities were significantly higher at a ROI of 2000:1 $\left(7.33 \times 10^{5} \mathrm{CFU} /\right.$ well) than at a ROI of $400: 1 \quad\left(1.53 \times 10^{5} \mathrm{CFU} /\right.$ well $)$ (Fig. 1). L. reuteri CRL 1324 exhibited poor internalization capabilities into the HeLa cells at the two ROI assayed $\left(6 \times 10^{2} \mathrm{CFU} /\right.$ well at a ROI of $2000: 1$, and $1.28 \times 10^{2} \mathrm{CFU} /$ well at an ROI of 400:1), which corresponds to less than 1 internalized bacteria per $400 \mathrm{HeLa}$ cells (data not shown).

Adhesion of lactobacilli to HeLa cells has been widely reported. For example, Joo et al. (2012) reported the adhesion of Lactobacillus helveticus HY7801 (a human vaginal isolate) to HeLa cells. Martín et al. (2012) showed that five human Lactobacillus strains strongly adhered to HeLa cells and suggested that aggregation-promoting factor-like proteins participate in the phenomenon. Verdenelli et al.

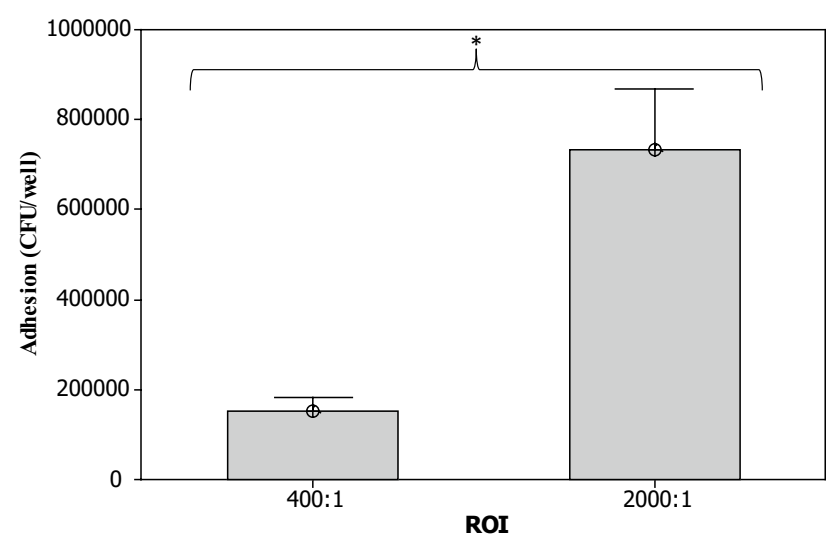

Fig. 1 Adhesion to HeLa cells of L. reuteri CRL 1324. L. reuteri CRL 1324 (ROI of 400:1 and 2000:1) populations adhered to HeLa cells were determined after $1 \mathrm{~h}$ of interaction. Data are presented as mean populations per well (i.e., corresponding to $2.5 \times 10^{5} \mathrm{HeLa}$ cells) + standard error. Each experiment was performed in triplicate, and differences between groups were compared using Student's $t$ test
(2014) evidenced that L. rhamnosus IMC 501, Lactobacillus paracasei IMC 502 and their SYNBIO (intestinal isolates) combination can adhere to HeLa cells, while these strains were able also to exert antimicrobial activity against pathogenic Candida strains. Parolin et al. (2015) demonstrated that the adhesive properties were different in several strains, with Lactobacillus crispatus $\mathrm{BC} 1$, L. crispatus $\mathrm{BC} 3$ and $L$. gasseri $\mathrm{BC} 8$ being the most adherent strains in their assay. The adherence of beneficial bacteria to eukaryotic cells is strain- and specie-specific usually being the mucus-binding proteins associated (Walsham et al. 2016; Hou et al. 2015). Walsham et al. (2016) showed that CmbA and MUB increase the binding of L. reuteri to both HT-29 and LS174T cells. In a previous work, the presence of genes encoding for a mucus adhesion-promoting protein (MapA), a mucus-binding protein (MubI) and a cell and mucus-binding protein (CmbA) was evidenced in L. reuteri CRL 1324 (Leccese Terraf et al. 2014), and further studies will be carried out to evaluate the involvement of these proteins in the adhesion process.

\section{Effect of $L$. reuteri CRL 1324 on the adhesion and internalization of $E$. coli to HeLa cells}

The adhesion of lactobacilli to the vaginal mucosa is significant to promote and help in the probiotic action (Martín et al. 2013). The effects of lactobacilli on different urogenital pathogens were demonstrated on HeLa cells, including Gardnerella vaginalis, Candida albicans by different authors (Joo et al. 2011, 2012; Parolin et al. 2015; Santos et al. 2016) and E. coli (Atassi et al. 2006).

In this study, L. reuteri CRL 1324 and E. coli 275 were co-incubated with HeLa cells to determine if the Lactobacillus strains can affect the pathogen adhesion. L. reuteri at a ROI of 2000:1 reduced the adhesion rate of $E$. coli at a MOI of 100:1, decreasing by $30 \%$ the adhesion observed with E. coli 275 (Fig. 2). However, L. reuteri CRL 1324 at a ROI of 400:1 did not significantly affect the adhesion rate of E. coli.

UPEC can invade host uroepithelial tissue and once internalized can persist in quiescence for long periods without causing clinical symptoms (Mulvey et al. 2001). The co-incubation of $L$. reuteri CRL 1324 and E. coli 275 with HeLa cells partially inhibited the pathogen internalization as shown in Fig. 3. L. reuteri CRL 1324 with a ROI of 400:1 and 2000:1 led to a significant decrease of $E$. coli internalization rates by $51-57 \%$. In the present work, the mechanism of competition between $L$. reuteri CRL 1324 and E. coli 275 for HeLa cell adhesion was assayed (coincubation of lactobacilli, HeLa cells and pathogen) and demonstrated. However, other researchers evaluated the mechanism of exclusion, through the incubation of lactobacilli and epithelial cells or mucus followed by pathogen 


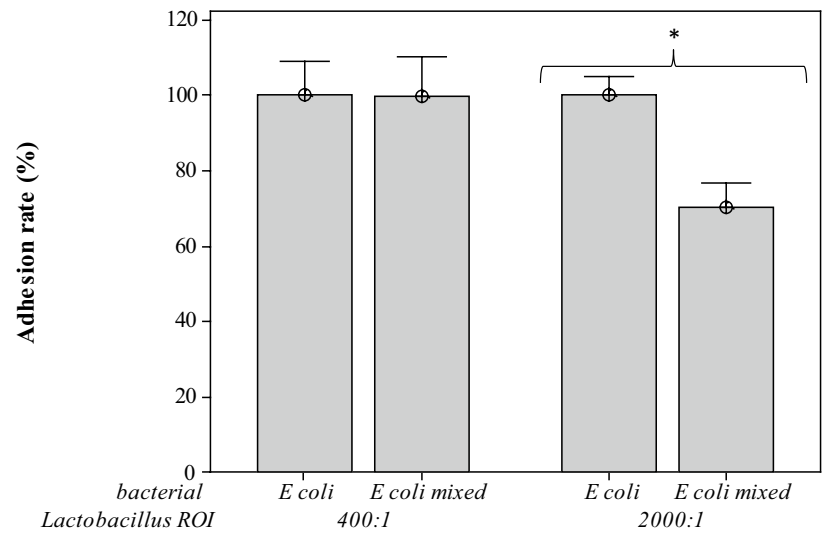

Fig. 2 Inhibition of E. coli 275 adhesion to HeLa cells by L. reuteri CRL 1324. Data show adhesion rates of E. coli 275 after $1 \mathrm{~h}$ of interaction with HeLa cells in the presence of $L$. reuteri CRL 1324 at a ROI of 400:1 and 2000:1. E. coli 275 was used at a MOI of 100:1. An adhesion assay of E. coli 275 alone was used as a reference. The adhered $E$. coli population in the reference experiment (corresponding to $100 \%$ adhesion rate) corresponds to $2.3 \times 10^{6} \mathrm{CFU} /$ well and $2.72 \times 10^{6} \mathrm{CFU} /$ well for the assay with $L$. reuteri at ROI $400: 1$ and 2000:1, respectively. Adhesion rates were then defined as the adhered E. coli 275 population in the presence of $L$. reuteri relative to the adhered E. coli 275 population in the reference experiment. Data are presented as means + standard error. Each experiment was done in triplicate, and differences between groups were compared using Student's $t$ test

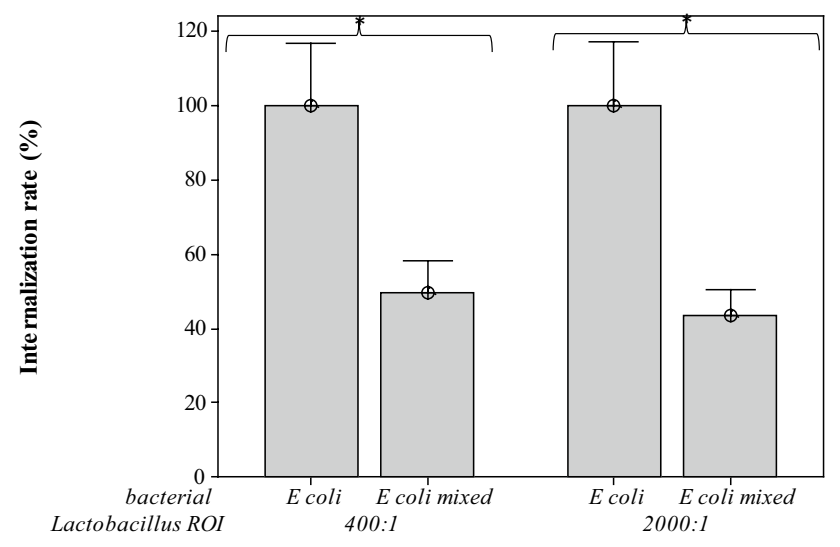

Fig. 3 Inhibition of E. coli 275 internalization into HeLa cells by L. reuteri CRL 1324. Data show internalization rates of E. coli 275 strain after $2 \mathrm{~h}$ of interaction with HeLa cells in the presence of $L$. reuteri CRL 1324 at a ROI of 400:1 and 2000:1. E. coli 275 was used at a MOI of 100:1. An internalization assay of E. coli 275 alone was used as a reference. The adhered $E$. coli population in the reference experiment (corresponding to $100 \%$ adhesion rate) corresponds to $2.24 \times 10^{2} \mathrm{CFU} /$ well and $4.60 \times 10^{2} \mathrm{CFU} /$ well for the assay with $L$. reuteri at ROI 400:1 and 2000:1, respectively. Internalization rates were then defined as the internalized $E$. coli 275 population in the presence of $L$. reuteri relative to the internalized $E$. coli 275 population in the reference experiment. Data are presented as means + standard error. Each experiment was done in triplicate, and differences between groups were compared using Student's $t$ test addition ( $\mathrm{Li}$ et al. 2008; Walsham et al. 2016). Walsham et al. (2016) demonstrated that the pre-incubation of gut symbiont $L$. reuteri strains inhibited enteropathogenic Escherichia coli (EPEC) binding to intestinal epithelial cells in a strain- and cell-dependent manner. L. reuteri ATCC PTA 6475 (a human isolate) and ATCC 53608 (a pig isolate) significantly inhibited EPEC binding to HT-29, but not to LS174T cells. In addition, these strains affected EPEC adherence to small intestinal biopsy epithelium.

During all the adhesion experiments and subsequent internalization assays, the density of the HeLa cells monolayer was maintained as controlled by cell counting. Thus, the lower adhered population of E. coli 275 to HeLa cells did not result from a smaller amount of attached HeLa cells in the wells when incubated with $L$. reuteri CRL 1324. The results obtained suggest that $L$. reuteri CRL 1324 could be able to compete with $E$. coli 275 for binding to some receptors on Hela cells. The ability of L. reuteri CRL 1324 to significantly reduce the adhesion and internalization of $E$. coli 275 is clinically relevant, because the pathogen adhesion and invasion on the host cells are main steps in the infection process.

Few studies have investigated the ability of LAB to modulate the internalization of pathogens on host cells. The results presented in this work are similar to those reported by Atassi et al. (2006), who demonstrated the inhibition of adhesion to and internalization into HeLa cells of $E$. coli IH11128 by adhering vaginal Lactobacillus strains. Delley et al. (2015) showed that L. johnsonii NCC533, L. johnsonii NCC2917 and L. rhamnosus NCC4007 (commercial probiotics) reduced the adhesion of two UPEC strains (E. coli UTI89 and E. coli CFT073) to human bladder cancer cell line UM-UC-3; however, the results were not significant.

\section{Conclusions}

The results obtained in this work indicate that $L$. reuteri CRL 1324 and L. rhamnosus CRL 1332 were able to in vitro inhibit the growth of UPEC strains by organic acids production. Also L. reuteri CRL 1324 inhibited E. coli 275 adherence to and internalization into HeLa cells. In this way, this strain can be proposed as a beneficial Lactobacillus, which could generate some type of protection against urogenital infections. In vivo trials are being performed to advance in the design of probiotics formulations for the prevention and/or treatment of urinary tract infections.

Acknowledgements This paper was supported by CONICET (ConsejoNacional de InvestigacionesCientíficas y Técnicas, Argentina) (PIP 744) and ANPCyT (AgenciaNacional de PromociónCientífica y Tecnológica) (PICT 2012-1187), and was partially performed within the framework of a Bilateral Cooperation Project (A12-B01) between Mincyt (Ministerio de Ciencia, Tecnología e Innovación Productiva 
de Argentina) and ECOS-SUD (France). The strains were licensed through a CONICET-BIOLIFE agreement.

\section{Compliance with ethical standards}

Conflict of interest The authors declare that they have no conflict of interest.

\section{References}

Almeida RA, Matthews KR, Cifrian E, Guidry AJ, Oliver SP (1996) Staphylococcus aureus invasion of bovine mammary epithelial cells. J Dairy Sci 79:1021-1026

Anderson GG, Goller CC, Justice S, Hultgren SJ, Seed PC (2010) Polysaccharide capsule and sialic acid-mediated regulation promote biofilm-like intracellular bacterial communities during cystitis. Infect Immun 78:963-975

Atassi F, Servin AL (2010) Individual and co-operative roles of lactic acid and hydrogen peroxide in the killing activity of enteric strain Lactobacillus johnsonii NCC933 and vaginal strain Lactobacillus gasseri KS120.1 against enteric, uropathogenic and vaginosis-associated pathogens. FEMS Microbiol Lett 304:29-38

Atassi F, Brassart D, Grob P, Graf F, Servin AL (2006) Vaginal Lactobacillus isolates inhibit uropathogenic Escherichia coli. FEMS Microbiol Lett 257(1):132-138

Baron F, Cochet MF, Ablain W, Grosset N, Madec MN, Gonnet F, Jan S, Gautier M (2006) Rapid and cost-effective method for microorganism enumeration based on miniaturization of the conventional plate-counting technique. Dairy Sci Technol 3:251-257

Beerepoot MA, terRiet G, Nys S, van der Wal WM, de Borgie CA, de Reijke TM, Prins JM, Koeijers J, Verbon A, Stobberingh E, Geerlings SE (2012) Lactobacilli vs antibiotics to prevent urinary tract infections: a randomized, double-blind, non inferiority trial in postmenopausal women. Arch Intern Med 172:704-712

Bouchard DS, Rault L, Berkova N, Le Loir Y, Even S (2013) Inhibition of Staphylococcus aureus invasion into bovine mammary epithelial cells by contact with live Lactobacillus casei. Appl Environ Microbiol 79(3):877-885

Bouchard DS, Seridan B, Saraoui T, Rault L, Germon P, GonzalezMoreno C, Nader-Macías FM, Baud D, François P, Chuat V, Chain F, Langella P, Nicoli J, Le Loir Y, Even S (2015) Lactic acid bacteria isolated from bovine mammary microbiota: potential allies against bovine mastitis. PLoS One 10(12):e0144831

Cadieux PA, Burton J, Devillard E, Reid G (2009) Lactobacillus by-products inhibit the growth and virulence of uropathogenic Escherichia coli. J Physiol Pharmacol 60(Suppl 6):13-18

De Man JC, Rogosa M, Sharpe ME (1960) A medium for the cultivation of lactobacilli. J Appl Bacteriol 23:130-135

De Gregorio PR, Juárez Tomás MS, Nader-Macías ME (2016) Immunomodulation of Lactobacillus reuteri CRL1324 on Group B Streptococcus Vaginal Colonization in a Murine Experimental Model. Am J Reprod Immunol 75(1):23-35

Delley M, Bruttin A, Richard M, Affolter M, Rezzonico E, Brück WM (2015) In vitro activity of commercial probiotic Lactobacillus strains against uropathogenic Escherichia coli. FEMS Microbiol Lett 362(13):fnv096

Ejrnaes K, Stegger M, Reisner A, Ferry S, Monsen T, Holm SE, Lundgren B, Frimodt-Møller N (2011) Characteristics of Escherichia coli causing persistence or relapse of urinary tract infections: phylogenetic groups, virulence factors and biofilm formation. Virulence 2:528-537

Falagas ME, Betsi GI, Tokas T, Athanasiou S (2006) Probiotics for prevention of recurrent urinary tract infections in women. A review of the evidence from microbiological and clinical studies. Drugs 66:1253-1261

FAO/WHO Report (2001) Evaluation of health and nutritional properties of powder milk and live lactic acid bacteria. http://www. fao.org/es/ESN/Probio/probio.htm. Accessed July 2016

Geerlings SE, Beerepoot MA, Prins JM (2014) Prevention of recurrent urinary tract infections in women: antimicrobial and nonantimicrobial strategies. Infect Dis Clin North Am 28(1):135-147

Gudiña EJ, Rocha V, Teixeira JA, Rodrigues LR (2010) Antimicrobial and antiadhesive properties of a biosurfactant isolated from $\mathrm{Lac}$ tobacillus paracasei ssp. Paracasei A20. Lett Appl Microbiol 50:419-424

Gupta K, Stapleton AE, Hooton TM, Roberts PL, Fennell CL, Stamm WE (1998) Inverse association of $\mathrm{H}_{2} \mathrm{O}_{2}$-producing lactobacilli and vaginal Escherichia coli colonization in women with recurrent urinary tract infections. J Infect Dis 178:446-450

Hill C, Guarner F, Reid G, Gibson GR, Merenstein DJ, Pot B, Morelli L, Canani RB, Flint HJ, Salminen S, Calder PC, Sanders ME (2014) Expert consensus document: the International Scientific Association for Probiotics and Prebiotics consensus statement on the scope and appropriate use of the term probiotic. Nat Rev Gastro Enterol Hepatol 11:506-514

Hou C, Zeng X, Yang F, Liu H, Qiao S (2015) Study and use of the probiotic Lactobacillus reuteri in pigs: a review. J Anim Sci Biotechnol 6(1):14

Human Microbiome Project Consortium (2012) Structure, function and diversity of the healthy human microbiome. Nature 486:207-214

Johnson JR, Russo TA (2005) Molecular epidemiology of extraintestinal pathogenic (uropathogenic) Escherichia coli. Int J Med Microbiol 295:383-404

Joo HM, HyunYJ, Myoung KS, Ahn YT, Lee JH, Huh CS, Han MJ, Kim DH (2011) Lactobacillus johnsonii HY7042 ameliorates Gardnerella vaginalis-induced vaginosis by killing Gardnerella vaginalis and inhibiting NF- $\mathrm{KB}$ activation. Int Immunopharmacol 11:1758-1765

Joo HM, Kim KA, Myoung KS, Ahn YT, Lee JH, Huh CS, Han MJ, Kim DH (2012) Lactobacillus helveticus HY7801 ameliorates vulvovaginal candidiasis in mice by inhibiting fungal growth and NF- $\kappa B$ activation. Int Immunopharmacol 14:39-46

Juárez Tomás MS, Zonenschain D, Morelli L, Nader-Macías ME (2005) Characterization of potentially probiotic vaginal lactobacilli isolated from Argentinean women. Br J Biomed Sci 62:170-174

Juárez Tomás MS, Saralegui Duhart CI, De Gregorio PR, Vera Pingitore E, Nader-Macías ME (2011) Urogenital pathogen inhibition and compatibility between vaginal Lactobacillus strains to be considered as probiotic candidates. Eur J Obstet Gynecol Reprod Biol 159:399-406

Leccese Terraf MC, Juárez Tomás MS, Nader-Macías ME, Silva C (2012) Screening of biofilm formation by beneficial vaginal lactobacilli and influence of culture media components. J Appl Microbiol 113:1517-1529

Leccese Terraf MC, Mendoza LM, Juárez Tomás MS, Silva C, NaderMacías ME (2014) Phenotypic surface properties (aggregation, adhesion and biofilm formation) and presence of related genes in beneficial vaginal lactobacilli. J Appl Microbiol 117:1761-1772

Li XJ, Yue LY, Guan XF, Qiao SY (2008) The adhesión of putative probiotic lactobacilli to cultured epitelial cells and porcine intestinal mucus. J Appl Microbiol 104(4):1082-1091

Martín R, Suárez JE (2010) Biosynthesis and degradation of $\mathrm{H}_{2} \mathrm{O}_{2}$ by vaginal lactobacilli. Appl Environ Microbiol 76:400-405

Martín R, Soberón N, Vaneechoutte M, Flórez AB, Vázquez F, Suárez JE (2008) Characterization of indigenous vaginal lactobacilli from healthy women as probiotic candidates. Int Microbiol $11: 261-266$ 
Martín R, Sánchez B, Suárez JE, Urdaci MC (2012) Characterization of the adherence properties of human Lactobacilli strains to be used as vaginal probiotics. FEMS Microbiol Lett 328(2):166-173

Martín R, Martín C, Escobedo S, Suárez JE, Quirós LM (2013) Surface glycosaminoglycans mediate adherence between HeLa cells and Lactobacillus salivarius Lv72. BMC Microbiol 13:210

Mirmonsef P, Gilbert D, Veazey RS, Wang J, Kendrick SR, Spear GT (2012) A comparison of lower genital tract glycogen and lactic acid levels in women and macaques: implications for HIV and SIV susceptibility. AIDS Res Hum Retrovir 28:76-81

Mobley HL, Donnenberg MS, Hagan EC (2009) Uropathogenic Escherichia coli. In: Böck A (ed) EcoSal-Escherichia coli and Salmonella: cellular and molecular biology. ASM Press, Washington, DC

Mulvey MA, Schilling JD, Hultgren SJ (2001) Establishment of a persistent Escherichia coli reservoir during the acute phase of a bladder infection. Infect Immun 69(7):4572-4579

Mysorekar IU, Hultgren SJ (2006) Mechanisms of uropathogenic Escherichia coli persistence and eradication from the urinary tract. Proc Natl Acad Sci USA 103:14170-14175

Nader-Macías MEF, Silva de Ruiz C, Ocaña VS, Juárez Tomás MS (2008) Advances in the knowledge and clinical applications of lactic acid bacteria as probiotics in the urogenital tract. Curr Women's Health Rev 4:240-257

Nielubowicz GR, Mobley HL (2010) Host-pathogen interactions in urinary tract infection. Nat Rev Urol 7:430-441

O'Hanlon DE, Moench TR, Cone RA (2013) Vaginal pH and microbicidal lactic acid when lactobacilli dominate the microbiota. PLoS One 8(11):e80074

Ocaña VS, Bru E, de Ruiz Holgado AP, Nader-Macías ME (1999a) Surface characteristics of lactobacilli isolated from human vagina. J Gen Appl Microbiol 45:203-212

Ocaña VS, Ruiz Holgado AP, Nader-Macias ME (1999b) Characterization of a bacteriocin-like substance produced by a vaginal $\mathrm{Lac}$ tobacillus salivarius strain. Appl Environ Microb 65:5631-5635

Oelschlaeger TA (2010) Mechanisms of probiotic actions-a review. Int J Med Microbiol 300:57-62

Parolin C, Marangoni A, Laghi L, Foschi C, Nahui Palomino RA, Calonghi N, Cevenini R, Vitali B (2015) Isolation of vaginal lactobacilli and characterization of anti-Candida activity. PLoS One 10(6): $\mathrm{e} 0131220$

Pitout JD (2013) Enterobacteriaceae that produce extended-spectrum $\beta$-lactamases and AmpC $\beta$-lactamases in the community: the tip of the iceberg? Curr Pharm Des 19:257-263
Pitout JD, Laupland KB (2008) Extended-spectrum beta-lactamaseproducing Enterobacteriaceae: an emerging public-health concern. Lancet Infect Dis 8:159-166

R development Core Team (2013) R: A Language and Environment for Statistical computing. R Foundation for Statistical Computing, Vienna, Austria. http://www.R-project.org. Accessed July 2016

Raibaud P, Galpin JV, Ducluzeau R, Mocquot G, Oliver G (1973) Le genre Lactobacillus dans le tube digestif du rat. I: Caractères de souches homofermentaires isolées de rats Holoet Gnotoxéniques. Ann Microbiol (Inst Pasteur) 124A:83-109

Razzak MS, Al-Charrakh AH, Al-Greitty BH (2011) Relationship between lactobacilli and opportunistic bacterial pathogens associated with vaginitis. N. Am J Med Sci 3:185-192

Santos CM, Pires MC, Leão TL, Hernández ZP, Rodriguez ML, Martins AK, Miranda LS, Martins FS, Nicoli JR (2016) Selection of Lactobacillus strains as potential probiotics for vaginitis treatment. Microbiology. doi:10.1099/mic.0.000302

Stapleton AE, Au-Yeung M, Hooton TM, Fredricks DN, Roberts PL, Czaja CA, Yarova-Yarovaya Y, Fiedler T, Cox M, Stamm WE (2011) Randomized, placebo-controlled phase 2 trial of a Lactobacillus crispatus probiotic given intravaginally for prevention of recurrent urinary tract infection. Clin Infect Dis 2:1212-1217

Stoyancheva G, Marzotto M, Dellaglio F, Torriani S (2014) Bacteriocin production and gene sequencing analysis from vaginal $\mathrm{Lac}$ tobacillus strains. Arch Microbiol 196:645-653

Vera Pingitore E, Bru E, Nader-Macias ME (2012) Effect of lyophilization and storage temperature on the activity of salivaricin CRL 1328, a potential bioactive ingredient of a urogenital probiotic product. J Gen Appl Microbiol 58(2):71-81

Verdenelli MC, Coman MM, Cecchini C, Silvi S, Orpianesi C, Cresci A (2014) Evaluation of antipathogenic activity and adherence properties of human Lactobacillus strains for vaginal formulations. J Appl Microbiol 116(5):1297-1307

Walsham AD, MacKenzie DA, Cook V, Wemyss-Holden S, Hews CL, Juge N, Schüller S (2016) Lactobacillus reuteri inhibition of enteropathogenic Escherichia coli adherence to human intestinal epithelium. Front Microbiol. doi:10.3389/fmicb.2016.00244

Witkin SS (2015) The vaginal microbiome, vaginal anti-microbial defense mechanisms and the clinical challenge of reducing infection-related preterm birth. BJOG 122:213-218 